DOI: $10.30520 / \mathrm{tj}$ sosci. 972872

\title{
HYPOCRISY AND FALLACY OF SOCIAL MEDIA FREEDOM ON NATIONAL SECURITY: MIRRORING THE 2021 TRUMP BLOCKAGE AGAINST SELECTED AFRICAN CASES
}

\author{
Blessing Simura ${ }^{1}$
}

\begin{abstract}
Social media are praised as arenas for free speech which came with emancipation and reversing authoritarian governments control of media. This article compares and contrasts the hypocrisy of the alleged promotion of free speech in Africa and the global South and denying it to Trump and his supporters in the USA when the messages had comparatively the same effects of fomenting 'public disorder' in the name of free speech. Using Facebook and Twitter as the case social media platforms of analysis, the paper critically reviewed literature related to the subject. It is observable that social media has often times promoted the circulation of violent and protest foment information in the global South, and regarded this as emancipatory and democratic. Whereas, in the global North, more specifically, by focusing on the 2020 USA's contested Presidential election, it is noted that social media companies quickly stepped in to block Donald Trump statements deemed to ignite political insurrection and glorification of violence. What we then observe is the hypocritical nature of social media platforms and a continued perpetuation of the centre- periphery prism hinged on maintain a hegemonic force on the global South states that do not own and control the social media platforms.
\end{abstract}

Key Words: Social Media, National Security, Donald Trump, Uprisings, Media Freedom

\footnotetext{
${ }^{1}$ Adjunct Lecturer, Midlands State University, Zimbabwe, blessingsimura @ gmail.com, ORCID Id: 00000002-2395-2026
} 


\begin{tabular}{l} 
Year:5, Volume:5, Number: $10 / 2021$ \\
\hline $\begin{array}{l}\text { Journal of } \\
\text { Social } \\
\text { Science }\end{array}$
\end{tabular}

\section{Introduction}

The social media are celebrated as liberalizing mass communication tools which have allowed the voiceless to have a voice. Particularly discussed at length is the role of the social media in dismantling the government hegemony on the traditional media and the emasculation of the traditional media moguls and the news editors from being the gatekeepers on information flows. Social media are free networks which manage to give communication powers to the ordinary people whose fear of government control is reduced and reprisals are minimized by ability to use pseudonyms (Mugari: 2020; Satell: 2014).

The social media are celebrated as key drivers of revolutions especially by the youths in mostly the global south, the Middle East, Eastern Europe and the Caucasus regions (Satell: 2014; Beaumont: 2011). Several studies analyse the role of social media in the Arab Spring which began at the end of 2010. Scholars, policy makers and even state leaders praised those who used the social media to unseat leaders who were variously defined as 'dictatorial', 'autocratic' and 'despotic'. Attempts to block social media, to censor leading users of social media to call for various uprisings was classified as undemocratic and autocratic. Cases as in the Zimbabwe government's downing of the internet in the wake of the unrest of January 2019 were labelled as undermining human rights (Charette: 2019; Aljazeera: 2019).

However, in the post 2020 presidential elections and the overrunning of the United States of America's (USA) Capitol Hill by supporters of the then USA President, Donald Trump, social media sites collaboratively blocked Trump's social media pages on the pretext that his messages on these sites were spreading falls and inflammatory messages, had incited violence in the period after the election and the inauguration of then President-Elect, Joseph Biden (Twitter Inc.: 2021; Wagner and Frier: 2021; Perrogo: 2021). Other users who were seen as ardent supporters of Trump were blocked as well. However, what happened in the USA in January 2021 is not different to what was happening to other countries in terms of established norms in changing leadership being overtaken by populist actions, which in those countries were dubbed popular.

In light of these events, this paper questions the seemingly hypocritical responses of social media companies to uprisings in America and outside USA orbit. The paper is a qualitative analysis of events and the impact of social media which uses document analysis as well as critical text and discourse analysis of various text. The paper extensively uses information from the social media particularly statements by Facebook owner, Mark Zuckerberg as well as various online newspaper articles that were reporting and discussing the unfolding of events in both North Africa and the Middle East from the end of 2010 as well as in the USA 


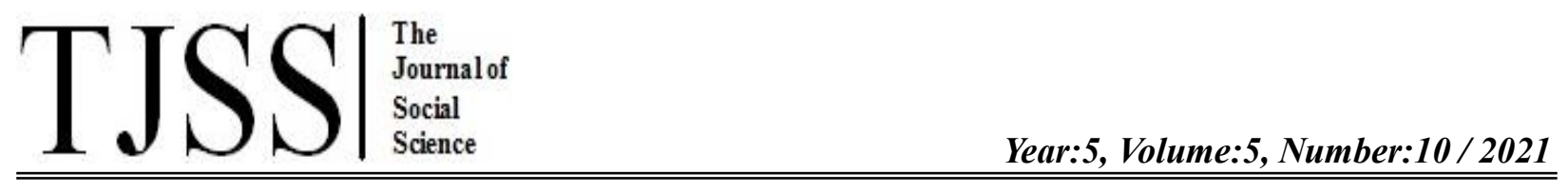

in 2021. Related academic and policy pronouncements literatures are also used. For comparative analysis, this paper limited itself to Africa (representing the global south) from the Arab springs (2011) to 2020.

\section{Social Media as the Arena of Free Speech}

Social media are seen as the arenas of free speech and arenas that transformed citizen journalism to a more meaningful level (Luo and Harrison: 2019; Mirvajova: 2014). With the advent of social media, people could now communicate their issues without being stopped by censorship systems and the editorial principles of certain media organizations.

Social media challenged the old theories of media especially the theory of agenda setting which were prevalent in the traditional print and broadcast media. Under the traditional media, editors and media owners were seen as having power to define media content and through this power direct what the public should be socio-politically and economically thinking of (Moyo: 2019). Through various control mechanism, government also influenced the agenda of the media and various media frame.

Social media also brought speedy communication, privately and publicly (Danspeckgruber: 2011). There was no longer need to wait for the next day for the next newspaper or for a certain hour to get breaking news. All what one needed would be a computer or a smartphone and internet connectivity. While social media was seen as a rival to the traditional media, the traditional media adapted quickly and in-cooperated social media as a source of breaking news (Mugari: 2020; Beaumont: 2011; Moore: 2011) and also as a tool for their various journalists to communicate news quickly.

While social media was quickly adopted by traditional media as a source of news and also as a to link with correspondents in faraway areas, independent media platforms that rivalled traditional media in many ways remained. In the traditional media, governments held tremendous power over the media and both the democratic and autocratic societies developed various mechanisms by which they influenced information flows. Direct and heavy-handed controls were adopted in autocratic states like in the Russia and in China. In liberal democracy states, subtle controls ranging from direct links with media personnel, use of secret agents, and legislative controls are used (Oswald: 2009; Akhavan-Majid: 1991).

The direct controls or intimidation driven media controls may not be effective unless in countries that have strong technological developments. China is one such country which has managed to tame social media in a manner that has continued to insulate the political system from any social media driven public agitations (Polyakova and Meserole: 2019). China has made it difficult for western based social media platforms like Facebook and Twitter to operate in the country. The public mostly use homegrown social media platforms like Weibo, which is like twitter, and WeChat akin to WhatsApp. While Russia has allowed the western 
social media applications to be accessible to the public, the state has a strong legal and surveillance regime that gives it control of the public. Hence, China and Russia have currently succeeded in maintaining that online agitation does not translate to offline upheaval.

The situation is different in less technologically developed countries in the global South, especially in Africa. The governments which had relied much on direct control of the media either through direct control of broadcasting or through stringent media laws that drove journalists and the public into self-censorship found themselves limited. The governments had little mechanisms of knowing who published what and when and with the cases of Facebook and Twitter, the use of what are termed as 'ghost accounts' or pseudonym means one cannot easily pin an account to an individual. These new developments mean that the governments in Africa have been emasculated on information controls. African governments now rely more on network shutdowns and internet shutdown/blackouts in crisis times to contain online agitation from becoming tragic offline uprisings. The Ethiopian government in 2019 and 2020 used internet shutdown to quell protests and growing insurgency as well as separatist insurrection (Human Rights Watch: 2020). The method was also used by Zimbabwe in January 2019 (Charette: 2019; Aljazeera: 2019.). The challenge internet shutdown is costly as these impacts on a number of businesses that use the internet for communication and services.

The power on information control remains with those who control the platforms that offer people the information. Some social media platforms have various policies governing the control of information that might be deemed to promote violence, terrorism, extremism and other crimes like child sexual exploitation. Twitter Inc. (2019) states that "we have a policy against content that glorifies acts of violence in a way that may inspire others replicate those violent acts and cause real offline harm, or events where members of a protected group were the primary targets or victims." The social medium defines glorification of violence celebrating, praising or condoning "violent crimes or violent events where people were targeted" because of their race, sexual orientation, ethnicity, religious affiliation gender, age or disability (Twitter, Inc.: 2019). Zuckerberg (2021) wrote on his Facebook page that, Trump's “decision to use his platform to condone rather than condemn the actions of his supporters at the Capitol building has rightly disturbed people in the US and around the world". Facebook (Online) states that,

We aim to prevent potential offline harm that may be related to content on Facebook. While we understand that people commonly express disdain or disagreement by threatening or calling for violence in non-serious ways, we remove language that incites or facilitates serious violence. We remove content, disable accounts and work with law enforcement when we believe that there is a genuine risk of physical harm or direct threats to public safety. 
Users can be suspended if they are found to be contravening these policies. However, these community rules are fluid and it would be difficult to judge statements which can result in offline harm or that would not, unless if one is dealing with militant organisations. There are only few cases, like the removal of a posting by a New Zealand terrorist on March 2019 (Waterson: 2019). The removal of Trump could have been influenced by behind-the-scenes communication with security and intelligence leaders of the USA. However, the act was seen as the peak of the power of owners of the communication technological industry, specifically those domiciled in the USA.

Social Media policies raise questions of media justice and fairness. How is a post or series of posts judged to be glorifying violence or not glorifying violence? For instance, when Trump referred to Republican Party supporters who stormed the Capitol, it was judged as glorification of violence, while on the other hand, when western leaders praised the violent demonstrations in Libya and Syria (Simura: 2014) which resulted in civil war, the social media companies did not judge the posts as glorifications of violence. Social media owners took pride that their platforms were instrumental in the upheavals which were repackaged as democratic revolution. Political leaders from France and Germany questioned the precedence which was being set by the companies and noted that it was a dangerous precedence which allowed non-sovereigns and non-judicial bodies to regulate in matters they might have personal interests (Chazan, Foy and Murphy: 2021).

However, theoretically the action in part gave life to the Agenda Setting theory. the theory notes that apart from the governments and the editors the media houses, media owners also have powers of being gatekeepers in the media industries. The notion that social media was an arena for free speech is at best limited. It can only relate to less developed countries in the global South from where the concern of social media companies is only earning profits with limited any moral duties of political and social stability. In the global North, specifically in the USA, the actions by the companies to block Trump and allies showed that the companies did not only pay attention to profits but also political stability for the continuation of their businesses. Therefore, a hypocrisy and sustaining of the Metropole-Periphery divide in the current setup is noticeable.

\section{Social Media and Political Disturbances in the Global South}

The global south has been an arena for political contestations whose reasons have been interpreted differently by various constituencies of analysts. The Arab Spring, which were political insurrections in North Africa and the Middle East, were classified by some scholars as social media revolutions (Salanova: 2012; Beaumont: 2011; Moore: 2011). Scholars like Alterman (2011) and Gladwell (2010) put forward that 
the role of social media in uprisings were minimal. Arguing that for a revolution or an insurrection to take place, there should be unifying grievances, and strong traditional social ties with activists or participants knowing each other physically, prior to taking actions regarded as socially and politically dangerous (Alterman: 2011; Gladwell: 2010). Lindgren (2013: 217) states that, "There are of course no social media revolutions. Conceptualizations like "Facebook revolution" or "Twitter revolution" are inherently technodeterministic." Alterman (2011) also argues that traditional forms of media, specifically the television, played a much more dominant role in countries that had minimal social media penetration.

What is accepted by both sides of the debate is that social media, just like the traditional forms of media before it, plays a key role and is used as means of some communication by various activists with Facebook being more prevalent in Tunisia while in Egypt Twitter was more dominant (Beaumont: 2011). Alterman (2011) while stating the dominance of television networks, particularly Al-Jazeera, and the role of traditional social networks accepts that when the uprisings were in motion, social media became prevalent with activists wanting to be seen globally and television cites using images from social media sites to make their stories credible. What should be accepted is that the centrality of social media is not to create grievances, as these are inherent in a particular society or country. Social media are information platforms which have the capacity to inflame grievances and to romanticize uprisings in a cinematic way. In most of these cases, there is the glorification of violence as was the case in the North African uprisings.

The role of social media in political upheavals has not been limited to north Africa alone on the continent. There have been attempts to use social media to drive political insurrections in sub-Saharan Africa. In Zimbabwe, efforts can be traced back to the Baba Jukwa Facebook Page in 2013 which attempted to incite people in urban areas to revolt against the government (Mugari: 2020). In 2016, a pastor in Zimbabwe, Evan Mawarire, created hashtag \#Thisflag which he used to lament the socio-economic decay in the country and later transformed it into a political movement that called for nationwide protest in July 2016 (Reuters: 2016). In Sudan, in 2019, Omar al Bashir was toppled by the military in the wake of widespread public uprisings (2018-2019), with social media being noted as having played a part in mobilizing for the uprisings (Bior: 2019; Elmileik and Khalil: 2019).

Most of the governments of the affected countries attempted to either block social media sites or the internet. During the Arab Spring, both Egypt and Libya attempted on closing social media to limit the amount of information that mobilized for the uprisings and also that which exposed security forces excesses in attempts to bring down the uprisings. In Zimbabwe the government did not only jam the social media but took down the internet as it attempted to also stop the use of Virtual Private Networks (VPNs) (Charette: 2019; Aljazeera: 2019). The actions of blocking social media sites or the internet was a clear sign to show that the social media was a catalyst to the political disturbances. 


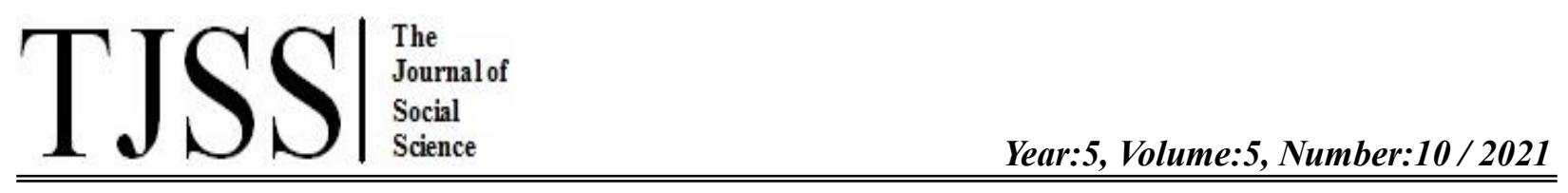

Blocking social media communications or the internet in general was interpreted as another sign of authoritarianism and an infringement to the rights of people to information. Western leaders argued that blocking the internet was an infringement on rights while not looking at the flipside of the uprisings (Charette: 2019; Aljazeera: 2019). As such there is no recorded case of a social media blocking by social media companies of activists in Africa for fomenting uprisings and insurrections.

\section{Post 2020 USA Elections: Different Rules?}

Post national government election periods are always the delicate times in any electoral democracy process in most past of the world. Examples abound of disputed elections which include all elections held in Zimbabwe since 2000, Malawi (2020), the Democratic Republic of Congo (DRC) (2019), the Gambia (2016), Gabon (2016), Ghana (2020), Kenya (2007 and 2017) and Tanzania (2020).

Post-election contestations have not been only a preserve of the so called young or fragile democracies but also the so-called established democracies. The results of the British's choice to exit the European Union were contested at various levels, regionally between England and Scotland and along generational divide (Kelly: 2016). In recent history, the outcome of the 2000 USA presidential elections between George W Bush and $\mathrm{Al}$ Gore were contested and it had to take a judgement by the Supreme Court to settle the matter (The Economic Times: 2020; Mann: 2001). The outcome of the 2016 presidential elections between Donald Trump and Hillary Clinton were marred by allegations of Russian meddling in favour of a Trump victory (Mueller: 2019).

These contestations were dealt with in a manner that did not raise public anger to boiling levels, as are cases in some other countries. It was the Democratic and Republican Parties contestations on the 2020 presidential as well as senate elections which tipped the tables and exposed the fallacy that social media was a free media which guaranteed unhindered speech. In the post-election period in which Trump was defeated by Joseph Biden, and the Republican Party lost dominance in both the Congress and the Senate to the Democratic Party. Donald Trump argued that his party and himself had been rigged. In the period leading to the confirmation of Biden and Kamala Harris as President-Elect and Vice President Elect, respectively, in a joint seating of the houses, Trump and his supporters, in series of tweets, Facebook posts, interviews and public speeches, urged supporters to fight for the white house and deny Biden to take over the Oval Office (Goodman, Dugas and Tonckens: 2021). The tweets used various words which included; fight, revolution, big protests among others (Goodman, Dugas and Tonckens: 2021). Trump supporters stormed the Capitol during the process, overpowered the police and the clashes led to the death of five 
people including a police officer (Evelyn: 2021). The events were taken by most American politicians as an assault on the dignity of the USA. To foe states of the USA, the events were a justification that the USA played a façade of democracy. To USA allies, the event was an embarrassment on a state viewed as a beacon of western democracy. The actions led some republicans who had intended to contest Biden and Harris' victory in the house to reconsider and support the election results as they were.

The social media, primarily Twitter and Facebook, were seen as having been the conduits through which Trump incited his supporters to come to Washington D.C. and storm the Capitol. Donald Trump had a lot of following on his social media pages. At the time of the suspension and blocking of his pages he had 88.7 million followers on Twitter and more than 30 million on Facebook. The figures were also translated on the ground by the big number of his political supporters which saw his getting " $74,222,958$ votes, or 46.8 percent of the votes cast", against Biden's " $81,283,098$ votes, or 51.3 percent of the votes cast" (Lindsay: 2020) in the 2020 elections. Trump had found it easier to communicate his views on social media after the traditional television was no longer giving him airplay, with a case point being the cutting off of his presidential address on 5 November 2020 by most leading television channels in the USA with the exception of CNN and Fox News, on the basis that he was peddling false statements on integrity of the elections results which were still being tallied in several states (Lyons: 2020; Grynbaum and Hsu: 2020; Joyella: 2020). While there were no recorded direct calls or public calls between state security and military personnel with social media companies, behind the scenes talks cannot be counted out. That Trump was now being taken as a serious national security threat was proven by the joint issuance of a statement by USA's top military officer that Biden was the new commander-in-chief post the inauguration and that they had a duty to protect the constitution of the USA (Shinkman: 2021). It was therefore not a surprise that the social media companies, blocked Trump, as he was already seen as a national security threat.

Social media companies laid the blame all on Trump and his supporters for having contested the results. This was an unfair judgement given that Trump represented the Republican Party whose members either openly or tacitly supported the arguments of electoral rigging by Trump. For instance, on the one hand, Senators Ted Cruz (Texas), Ron Johnson (Wisconsin), Josh Hawley (Missouri), James Lankford (Oklahoma), Steve Daines (Montana), John N. Kennedy (Louisiana), Marsha Blackburn (Tennessee), and Mike Braun (Indiana) and Senators-elect; Cynthia M. Lummis (Wyoming), Roger Marshall (Kansas), Bill Hagerty (Tennessee) and Tommy Tuberville (Alabama) stated that they would oppose the certification of the Biden-Harris Victory in a joint seating of Congress and Senate (Pengelly and Bryant: 2021; Broadwater: 2021). On the other hand, the Republican party never issued a statement to support the electoral outcome and censor Trump. Those who were questioned by the media either tacitly supported Trump, denied to comment or issued vague comments about the need to have a transparent electoral process (Barrett, Raju 
and Foran: 2020). It was only individual members who issued statements against Trump like Mit Romney (Barrett, Raju and Foran: 2020). Vice President Mike Pence, before the sitting to confirm the results in the House, had indicated a tacit support to challenging the Electoral College results (Broadwater: 2021). This shows that there was an implied party consensus that the presidential elections had been rigged in favour of the Democrats, or simply an acceptance that there was gross fraud which warranted the questioning of the process. Hence, for social media platforms to censor a few individuals in the name of democracy could have been a façade to protect a system portrayed as a global template of democracy beyond flaws. What Trump and the Republicans had done was proverbially the piercing of the 'God-king' exposing to the world that he bleeds. Hence, social media sites came out in full force in defence of the state and to cover up against an all-out challenge with the Republican Party, Trump and some of his associates like former National Security Advisor, Michael Flynn, were targeted.

Facebook owner, Mark Zuckerberg, on 7 January 2021, in justifying the banning of Trump from Facebook and Instagram, posted on his Facebook wall that the sites had policies which did not allow them to be used for the provocation of violent insurrections against established democratic norms in the USA. Twitter Inc. (2021) stated that,

...the President's statements can be mobilized by different audiences, including to incite violence, .... After assessing the language in these Tweets ..., we have determined that these Tweets are in violation of the Glorification of Violence Policy and the user @ realDonaldTrump should be immediately permanently suspended from the service.

However, what is a fact is that social media companies, in the name of stability and protecting established norms, barred a leader from communicating with his more than 74 million supporters. It was a case of an exercise of gross power which ironically stood as an affront to the democratic norms which the same platforms argued to be protecting.

What was apparent in the case of the USA was that Trump had a lot of online and offline followers. Some of his supporters were prepared to undertake demonstrations and insurrections, against the removal of Trump from office. This was proven by the insurrection at the Capitol Hill on 6 January 2021. Be it is at may; it is imperative to note that Trump supporters' actions were not only actions driven by the 'rants of a madman'. They were driven by a firm conviction that their Presidential and some of their (Republican) Senatorial Candidates had been unfairly defeated at the polls which they alleged to have been abetted by respective state electoral institutions. In a Quinnipiac University poll, “77\% of Republicans believe there was widespread voter fraud during the November election between President Donald Trump and Democrat Joe Biden," while among independent voters, $35 \%$ believed that there was widespread fraud (Keating and Courant: 2020). In a Fox News Poll conducted between 6 and 9 December 2020, 68.5\% of Republican 
supporters and $77 \%$ of Trump Voters believed that the presidential election was stolen from Donald Trump. In general, $36 \%$ of respondents believed that the election was stolen from Trump while $6 \%$ did not know while $58 \%$ stated that it was not stolen. In a country which claims a long history of perfecting democracy, the 36 percentage points of belief in a fraud was a failure of great proportions.

Had the belief and conviction been with supporters only, one would argue that they had been psyched for a long time by Trump to believe that the election would be rigged. The conviction was also shared by leading Republican members. As earlier noted, a number of the Republican Party Senators firmly believed that the electoral process of 2021 had been rigged in favour of the Democratic Party Presidential and some Senatorial Candidates. This conviction, if one makes a comparative balancing with Africa and the USA response to similar results, are a justified reason for mass demonstrations. It was in similar cases in Africa, where in most cases government controlled traditional broadcasting and print media would be in support of the victors that social media was touted as an alternative for those alleging rigging and being blocked from the mainstream media. However, in the USA the conviction of electoral victory of a candidate, his supporters and a party were sacrificed for national stability and continuity of an age-old practice without allowing them free speech. The leading social media companies, can be viewed as not different to the Chinese and Russian models, who the USA have sustainably attacked for lack of media freedoms.

In respect of the claims to glorifying violence, parallels can be drawn with the Libyan uprising, the Zimbabwean January 2019 demonstrations and also the 2018/19 Sudanese uprising. The demonstrations and insurrections glorified unconstitutional change of governments in these countries. In the Libyan case, the rebels were already armed when the government forces of Muammar Ghaddafi were attempting to stop them especially from their main stronghold in Benghazi (Foss: 2012). Lindgren's (2013) study shows that individual and group Twitter activists account like @ ShababLibya and @EnoughGaddafi, had statements which glorified violence. Statements like "\#Benghazi your city is calling you, Take to the streets. head for Maydan al Shajara \#Feb17 \#Libya” by @ShababLibya and "\#libya is revolting. we're organizing a protest at the downtown library, 1pm on saturday. come out. \#feb17 \#gaddafi is going down", by one popular activist (Lindgren, 2013: 216) clearly called for people to revolt and if weighed against the tweets by Trump, these are equally in the same category. Keen (2011: 11) shows that the uprising in Libya was violent from the onset when he states that, "However, the unrest in Benghazi continued into the following day as protestors began hurling stones and homemade incendiary devices at police attempting to disperse the rally with rubber bullets and water cannons. The situation soon unravelled as protestors set fire to cars and a police headquarters." The first day of mass protest, 17 February 2011 was publicised with violent connotations as a "day of revolt" (Foss, 2012: 19) or a "Day of Rage" (Keen: 2011; Simura: 2014). Foss (2012) and Simura (2014) note that events in Libya was a clear insurrection given that rebels attacked a 
military establishment and were armed in less than a week of the revolt. Pedde (2017: 95) put forward that, "From the beginning, the coordinated series of actions, the availability of a large quantity of weapons and ammunition, and the existence of a series of targets on the ground clearly demonstrated the presence of a plan, something which is incompatible with a simple riot." In spite of all this, social media corporations did not block users for promoting anarchy and advocating for challenging established norms. One would argue that they marvelled as western analysts glorified their tools for having been vehicles to democratisation (Alterman: 2011).

\section{Conclusion}

The article reveals the hypocrisy of prominent social media companies (Facebook and Twitter) in handling socio-political driven messages that impact on violence and the stability of national state entities. The rise of social media entities had been praised as a reversal of classical media theories that apportioned power on control of the information between governments and media house. The rise of social media was seen as the rise of a new era where the power on information flows was now in the hands of the ordinary people who no longer became mere audiences, but also got the power to question mainstream media and also became journalists in their own right as they could produce content which mainstream media companies would even adopt for their content as is during periods of natural disasters and political upheavals.

A comparative analysis of the responses of social media companies in African crises and in the post 2020 USA elections shows that, firstly, there is a differentiation in reaction whenever social media is used in actions that are deemed to foment violence or its prolongation. Secondly, at theoretical level, the responses have shown that the celebration of social media as platforms of free speech and liberation of the masses is at times a façade. Owners of the companies and political and security institutions from which the companies are domiciled still hold sway. What is learnt from the events is that national security is very much prioritized in the USA and the global North that even a president and supporters of his political party can be shut - off the communication lines, while in Africa the metropole seeks to export the exact opposite, where in the name of freedom of speech, the aggregate security of the whole nation could be sacrificed, and the same tools (social media platforms) are given polar uses. The social media platforms, far from being tools of media and general emancipation in Africa and the global South, should be seen as reinforcing the hegemonic control of the USA and the global North on the global South. Therefore, the diverse use and governance of social media in the wake of political processes calls for nation states and social media corporates to rethink and come up with a joint administration/ governing process that will clarify what is 'violent' behaviour' when to institute internet blockades and social medic account suspension. At the same 
time, at the social front, there is an urgent need to create progressive awareness campaigns that enlighten the citizenry on the ills of the wrong use of social media.

\section{Bibliography}

Akhavan-Majid, R. (1991), “American Mass Media and the Myth of Libertarianism: Toward an 'Elite Power Group' Theory," Mass Communication Faculty Publications, St. Cloud State University, Vol. 10, pp. 1-14, accessed $29 \quad$ January 2021, https://repository.stcloudstate.edu/cgi/viewcontent.cgi?article=1010\&context=comm_facpubs Aljazeera, (2019), "Zimbabwe Imposes Internet Shutdown amid Crackdown on Protests," 18 January, accessed 29 January 2021, https://www.aljazeera.com/news/2019/1/18/zimbabwe-imposes-internetshutdown-amid-crackdown-on-protests

Alterman, J. B. (2011), "The Revolution Will Not Be Tweeted,” The Washington Quarterly, Vol. 34(4), pp. $103-116$

Barrett, T. Raju, M. and Foran, C. (2020), “Top Republicans Defend Trump on Baseless Voter Fraud Claims as Concerns Grow in the Ranks," CNN, 6 November, accessed 26 January 2021, https://edition.cnn.com/2020/11/05/politics/election-2020-congressional-republicans-trump-electionfraud/index.html

Beaumont, P. (2011), "The Truth about Twitter, Facebook and the Uprisings in the Arab World," The Guardian, $25 \quad$ February, $\quad$ accessed $13 \quad$ January 2021, https://www.theguardian.com/world/2011/feb/25/twitter-facebook-uprisings-arab-libya

Bior, A. (2019), “Sudan's Social Media Deemed Major Player in Bashir's Ouster," Voice of America, 18 April, accessed 29 January 2021, https://www.voanews.com/archive/sudans-social-media-deemed-majorplayer-bashirs-ouster

Broadwater, L. (2021), "Pence Welcomes Futile Bid by GOP Lawmakers to Overturn Election," The New York Times, 2 January 2021, accessed 12 January 2021, https://www.nytimes.com/2021/01/02/us/politics/gop-senators-josh-hawley-election.html Charette, R. N. (2019), "Zimbabwe Government Blocks Internet to Suppress Protests, Cuts Power as a Result," Spectrum, 17 January, accessed $30 \quad$ January 2021, https://spectrum.ieee.org/riskfactor/telecom/internet/zimbabwe-government-cuts-internet-to-suppressfuel-price-protests 
Chazan, G., Foy, H. and Murphy, H. (2021), “Angela Merkel Attacks Twitter over Trump Ban,” Financial Times, 11 January, accessed 20 January 2021, https://www.ft.com/content/6146b352-6b40-48ef-b10ba34ad585b91a

Danspeckgruber, W. (2011), "Introduction," in Social Media Revolutions: All Hype or New Reality? Liechtenstein Institute on Self Determination, Princeton University, Princeton, pp. 3

Elmileik, A. and Khalil, S. (2019), “'Tasgut bas' to \#SudanUprising: How Social Media Told the Story,” Aljazeera, 12 August, accessed 29 January 2021, https://www.aljazeera.com/features/2019/8/12/tasgutbas-to-sudanuprising-how-social-media-told-the-story

Evelyn, K. (2021), "Capitol Attack: The Five People who Died," The Guardian, 8 January, accessed 30 January 2021, https://www.theguardian.com/us-news/2021/jan/08/capitol-attack-police-officer-five-deaths Facebook (Online), “Community Standards: Violence and Criminal Bahaviour," accessed 26 January 2021, https://www.facebook.com/communitystandards/violence criminal behavior

Foss, A. B. (2012), “The Libyan Rebellion: With Media as a Weapon; A Study of a Modern Insurgency's Effort to Influence International Media," Unpublished Master's Thesis, University of Oslo, May

Fox News Poll, (2020), Conducted 2-9 December and partly released on 11 December, accessed 26 January

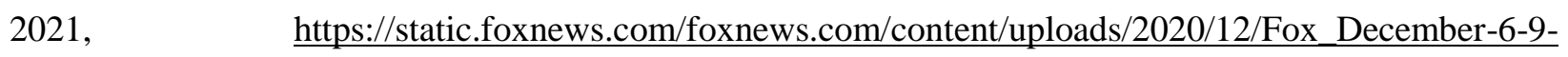
2020_National_Topline_December-11-Release.pdf

Gladwell, M. (2010), "Small Change: Why the Revolution will not be Tweeted," The New Yorker, 27 September, accessed 14 January 2021, https://www.newyorker.com/magazine/2010/10/04/small-changemalcolm-gladwell

Goodman, R. Dugas, M. and Tonckens, N. (2021), “Incitement Timeline: Year of Trump's Actions Leading to the Attack on the Capitol," Just Security, 11 January, accessed 29 January 2021, https://www.justsecurity.org/74138/incitement-timeline-year-of-trumps-actions-leading-to-the-attack-onthe-capitol/

Grynbaum, M. M. and Hsu, T. (2020), “Major Networks Cut Away from Trump's Baseless Fraud Claims,” The New York Times, 5 November, accessed 26 January 2021, https://www.nytimes.com/2020/11/05/business/media/trump-tv.html

Human Rights Watch, (2020), "Ethiopia: Communications Shutdown Takes Heavy Toll," 9 March, accessed 20 January 2021, https://www.hrw.org/news/2020/03/09/ethiopia-communications-shutdown$\underline{\text { takes-heavy-toll }}$

Joyella, M. (2020), "Broadcast Networks All Cut Away from President Trump's Election Remarks," Forbes, $\quad 5 \quad$ November, $\quad$ accessed $26 \quad$ January 
https://www.forbes.com/sites/markjoyella/2020/11/05/broadcast-networks-all-cut-away-from-presidentselection-remarks/?sh=433d37433eb0

Keating, C. and Courant, H. (2020), "Quinnipiac Poll: 77\% of Republicans Believe there was Widespread Fraud in the Presidential Election; 60\% Overall Consider Joe Biden's Victory Legitimate," Yahoo News, 10 December, accessed 26 January 2021, https://news.yahoo.com/quinnipiac-poll-77-republicans-believe204100654.html

Keen, T. (2011), "The Libyan Uprising and the Right of Revolution in International Law," International and Comparative Law Review, Vol, 11(1), pp. 7-32

Kelly, J. (2016), “Brexit: How Much of a Generation Gap is There?” BBC, 24 June, accessed 29 January 2021, https://www.bbc.com/news/magazine-36619342

Lindgren, S. (2013), “The Potential and Limitations of Twitter Activism: Mapping the 2011 Libyan Uprising," Triple C, Vol. 11(1), pp. 207-220

Lindsay, J. M. (2020), “The 2020 Election by the Numbers," Council on Foreign Relations, 15 December, accessed 14 January 2021, https://www.cfr.org/blog/2020-election-numbers

Luo, Y. and Harrison, T. M. (2019), "How Citizen Journalists Impact the Agendas of Traditional Media and the Government Policymaking Process in China," Global Media and China, Vol. 4 (1), pp. 72-93

Lyons, K. (2020), “TV networks cut away from Trump's 'most dishonest speech' ever,” The Verge, 5 November, accessed 26 January 2021, https://www.theverge.com/2020/11/5/21551991/twitter-cablebroadcast-networks-cut-away-trump-speech

Mann, T. E. (2001), "Reflections on the 2000 US Presidential Elections," Brookings, 1 January, accessed 29 January 2021, https://www.brookings.edu/articles/reflections-on-the-2000-u-s-presidential-election/ Moore, J. (2011), “Social Media: Did Twitter and Facebook Really Build a Global Revolution?” The Christian Science Monitor, 30 June, accessed 13 January 2021, https://www.csmonitor.com/World/GlobalIssues/2011/0630/Social-media-Did-Twitter-and-Facebook-really-build-a-global-revolution

Moyo, N. (2019), “The Effects of Social Media on Setting the Agenda of Traditional Media," Unpublished Master's Thesis, University of South Africa, January

Mueller, R. S. (2019), "Report on the Investigations into Russian Interference in the 2016 Presidential Election," Vol. 1, U.S. Department of Justice, Washington, D.C. March, accessed 29 January 2021, https://www.justice.gov/storage/report.pdf

Mugari, I. (2020), "The dark Side of Social Media in Zimbabwe," Cogent Social Sciences, Vol. 6(1), pp. $1-15$

Oswald, K. A. (2009), "Mass Media and the Transformation of American Politics," Marquette Law Review, Vol. 77 (385), pp. 385-414 
Pedde, N. (2017), “The Libyan Conflict and its Controversial Roots,” European View, Vol. 16, pp. 93-102 Pengelly, M. and Bryant, M. (2021), "Ted Cruz and other Republican Senators Oppose Certifying Election Results," The Guardian, 3 January, accessed 26 January 2021, https://www.theguardian.com/usnews/2021/jan/02/ted-cruz-republican-senators-reject-election-result-biden-trump

Perrigo, B. (2021), “Facebook and Twitter Finally Locked Donald Trump's Accounts. Will They Ban Him Permanently?” Time, 7 January, accessed 13 January 2021, https://time.com/5927398/facebook-twittertrump-suspension-capitol/

Polyakova, A. and Meserole, C. "Exporting Digital Authoritarianism: The Russian and Chinese Models," Brookings Foreign Policy Brief, accessed 3 February 2021, https://www.brookings.edu/wpcontent/uploads/2019/08/FP_20190827_digital_authoritarianism_polyakova_meserole.pdf

Salanova, R. (2012), "Social media and political change: The case of the 2011 revolutions in Tunisia and Egypt,” Institut Catala Internacional per La Pau (ICIP) Working Papers 2012/7

Satell, G. (2014), "If You Doubt that Social Media has Changed the World, Tale A Look at Ukraine," Forbes, 18 January, accessed 30 January 2021, https://www.forbes.com/sites/gregsatell/2014/01/18/if-youdoubt-that-social-media-has-changed-the-world-take-a-look-at-ukraine/?sh=2f6df4c $44 \mathrm{a} 2 \mathrm{c}$

Shinkman, P. D. (2021), “Military's Top Officers Defy Trump, Supporters, Denounce Violence in New Rare Statement," U.S. News, 12 January, accessed 30 January 2021, https://www.usnews.com/news/national-news/articles/2021-01-12/militarys-top-officers-defy-trumpsupporters-denounce-violence-in-new-rare-statement

Simura, B. (2014), "Military Intervention and International Law: A Critical Analysis of the Role of the International Community in Political Uprisings in Libya and Syria," Unpublished Doctoral Thesis, University of KwaZulu Natal, November

The Economic Times, (2020), "Bush Versus Gore in 2000: The Five Weeks of High Drama that Gave President Trump Precedent," 6 November, accessed 29 January 2021, https://m.economictimes.com/news/international/world-news/bush-versus-gore-in-2000-the-five-weeksof-high-drama-that-give-president-trump-precedent/articleshow/79053842.cms

Twitter Inc. (2021), “Permanent suspension of @realDonaldTrump,” 8 January, accessed 13 January 2021, https://blog.twitter.com/en_us/topics/company/2020/suspension.html

Twitter Inc. (2019), "Glorification of Violence Policy," March, accessed 8 January 2021, https://help.twitter.com/en/rules-and-policies/glorification-of-violence

Wagner, K. and Frier, S. (2021), “Trump Suspended by Twitter, Facebook, Snap in Riot's Wake," Bloomberg, 7 January, accessed 13 January 2021, https://www.bloomberg.com/news/articles/2021-01$\underline{07 / \text { twitter-suspends-trump-s-account-blocks-posts-as-riots-flare }}$ 
Year:5, Volume:5, Number:10/2021
$\begin{aligned} & \text { The } \\ & \text { Journal of } \\ & \text { Social } \\ & \text { Science }\end{aligned}$

Waterson, J. (2019), "Facebook Removes 1.5m Videos of New Zealand Terror Attack in First 24 Hours,"

The Guardian, 17 March, accessed 30 January 2021,

https://www.theguardian.com/world/2019/mar/17/facebook-removed-15m-videos-new-zealand-terror-

attack

Zuckerberg, M. (2021), Facebook post on the justification of blocking Trump on Facebook and Instagram,

7 January, accessed 13 January 2021, https://www.facebook.com/zuck 